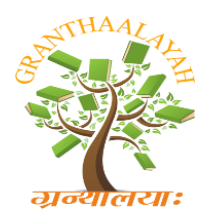

INTERNATIONAL JOURNAL OF RESEARCH GRANTHAALAYAH

A knowledge Repository

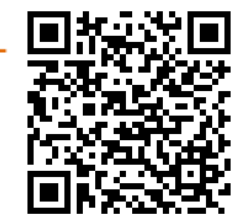

Management

\title{
FINANCIAL PERFORMANCE OF KANYAKUMARI DISTRICT COOPERATIVE MILK PRODUCERS UNION (KDCMPU)
}

\author{
Dr. V. Darling Selvi ${ }^{* 1}$ \\ *1 Assistant Professor of Commerce, Rani Anna Government College for Women, Tirunelveli-8, \\ INDIA
}

\begin{abstract}
The co-operative movement in Kanyakumari district has played a significant role in the social and economic development of the district, particularly in rural areas. Dairy co-operative movement in the district has contributed significantly towards the substantial increase in milk production. The main focus of this paper is to highlight the financial performance of Kanyakumari District Cooperative Milk producers Union. For this purpose the researcher used Creditor's Turnover Ratio, Current Ratio, Dairy, Debt Equity Ratio, Gross Profit Ratio, Net Profit Ratio, Proprietary Ratio, Quick Ratio, Return on Investment, Stock Turnover Ratio, Return on Assets and Return on Investment. The result reveals the fact that the financial performance of Aavin industry in Kanyakumari District is good in all the aspects. As there is wider scope for the production as well as consumption of milk and milk products in the district, efforts can be made to reduce the cost and to maximize the profit to make the milk industry $a$ vibrant and viable one in the district and state.
\end{abstract}

Keywords:

Creditor's Turnover Ratio, Current Ratio, Dairy, Debt Equity Ratio, Gross Profit Ratio, Net Profit Ratio, Proprietary Ratio, Quick Ratio, Return on Investment, Stock Turnover Ratio, Return on Assets, Return on Investment.

Cite This Article: Dr. V. Darling Selvi, "FINANCIAL PERFORMANCE OF KANYAKUMARI DISTRICT COOPERATIVE MILK PRODUCERS UNION (KDCMPU)" International Journal of Research - Granthaalayah, Vol. 4, No. 4: SE (2016): 29-40.

\section{INTRODUCTION}

Livestock sector plays a major role in the economy of the State. Animal Husbandry provides livelihood and is the mainstay of small and marginal farmers. Farm cultivation is seasonal in nature. The low cropping intensity coupled with a large number of small and marginal farmers and landless labourers, subsistence farming does not fetch adequate returns from land. The cooperative movement in Kanyakumari district has played a significant role in the social and economic development of the district, particularly in rural areas. Dairy co-operative movement in the district has contributed significantly towards the substantial increase in milk production. To 
meet the overgrowing demand of milk and milk products, various policies and programmes were launched in Tamil Nadu to further accelerate milk production. The dairy development department in the district promotes dairying as a supplementary occupation and brings incremental income to the famers, particularly in backward areas. Subsequently, the primary milk producers' co-operative society came into existence in the district. Kanyakumari is identified as one of the eight districts for strengthening dairy activities in the State under the Government of India's Intensive Dairy Development Program.

\section{KANYAKUMARI DISTRICT COOPERATIVE MILK PRODUCERS UNION (KDCMPU)}

District Co-operative Milk Producers' Union is the second level of the three-tier structure of the dairy co-operatives in the state. As per the scheme, these unions is entrusted with the task of procurement, processing and marketing of milk and milk products, as well as supply of inputs to milk producers through primary societies. It has to act as a connecting link between the primary societies and urban consumers. The membership of the district milk producers union consists of all registered primary milk producers societies in the area. Kanyakumari district is primarily an agriculture district with a sizable population depending on food crops and commercial crops. Dairy farming plays an important role in generating employment, income and capital storage, apart from and improving household nutrition in this district. In urban areas, the livestock owners adopt it as a fully fledged business for earning of livelihood. Kanyakumari District Cooperative Milk producers Union NO.2946, was first registered as Nanjil Nadu Milk Supply Society on $25^{\text {th }}$ January 1949 and started its functioning from 7th February 1950. Later it was elevated as Nanjil Nadu Milk Supply Cooperative Union by January 1951. During 1961 it was renamed as Kanyakumari District Cooperative Milk Supply Union. Later it was converted as Kanyakumari District Cooperative Milk Producers Union on $16^{\text {th }}$ February 1982. This Dairy is located at Nagercoil, the Head Quarters of this District. District Co-operative Milk Producers' Union is the second level of the three-tier structure of the dairy co-operatives in the state. To cater the needs of the public the union needs an average of 19000 litres of milk per day and hence they lift about an average of 10,000 litres per day from neighbouring dairy viz. Tirunelveli district co-operative milk producers union. The union produced by products like milk peda, Badam mix powder, flavoured milk and Butter milk and sales to the public.

\section{FINANCIAL PERFORMANCE OF KANYAKUMARI DISTRICT COOPERATIVE MILK PRODUCERS UNION}

Ratio Analysis: Ratios are highly important profit tools in financial analysis that help financial analysts implement plans that improve profitability, liquidity, financial structure, reordering, leverage, and interest coverage. Although ratios report mostly on past performances, they can be predictive too, and provide lead indications of potential problem areas. Ratio analysis is primarily used to compare a company's financial figures over a period of time, a method sometimes called trend analysis.

Current Ratio: This ratio indicates the rupees of current assets available for each rupee of current Liability. By this ratio we can see the stability of the firm or short term financial position of the firm. This test of solvency balances the current assets against the current liabilities. The 
current ratio will disclose balance sheet changes that net working capital will not. The ratio is calculated as follows: Current Ratio= Current Assets/Current Liabilities

Table 1: Current Ratio

\begin{tabular}{|l|l|l|l|l|l|l|}
\hline Year & $\begin{array}{l}\text { Current } \\
\text { Assets }\end{array}$ & $\begin{array}{l}\text { Trend } \\
\text { \% }\end{array}$ & $\begin{array}{l}\text { Current } \\
\text { Liability }\end{array}$ & $\begin{array}{l}\text { Trend } \\
\%\end{array}$ & $\begin{array}{l}\text { Current } \\
\text { Ratio }\end{array}$ & $\begin{array}{l}\text { Trend } \\
\%\end{array}$ \\
\hline 2006 & 19909290.2 & 100 & 10904221 & 100 & 1.83 & 100 \\
\hline 2007 & 19336427 & 97 & 10675663 & 98 & 1.81 & 99 \\
\hline 2008 & 23046767 & 116 & 15087836 & 138 & 1.53 & 84 \\
\hline 2009 & 23270773 & 117 & 13302519 & 122 & 1.75 & 96 \\
\hline 2010 & 40863311 & 205 & 19771186 & 181 & 2.07 & 113 \\
\hline 2011 & 50339664.8 & 253 & 24280474 & 223 & 2.07 & 114 \\
\hline 2012 & 64648714 & 325 & 36118351 & 331 & 1.79 & 98 \\
\hline 2013 & 158516882 & 796 & 32942965 & 302 & 4.81 & 264 \\
\hline 2014 & 196461236 & 987 & 32065737 & 294 & 6.13 & 336 \\
\hline Average & 66265896.06 & 333 & 21683216.92 & 199 & 2.64 & 145 \\
\hline r & $\mathbf{0 . 8 6}$ & & $\mathbf{0 . 9 3}$ & & $\mathbf{0 . 7 5}$ & \\
\hline
\end{tabular}

Source: Compiled from the records of KDCMPU

According to the standards the Current Ratio of the firm should be $2: 1$, but the ratios of the company couldn't reach the target during the years 2006 (1.83), 2007 (1.81), 2008 (1.53), 2009 (1.75) and 2012 (1.79). The ratios are above standard during the years 2010 (2.07), 2011 (2.07), 2013 (4.81) and 2014 (6.13). The average current ratio over the years under study has crossed the standard with 2.64. Hence it can be concluded that the Aavin Industry in Kanyakumari District is good at its liquidity position as far as the current ratios are concerned. The ratio is high in the year current year 2014. The position is further depicted with the correlation analysis, though it is positive in all the three cases, the highest figure is recorded for current liabilities (0.93), the current assets (0.86), and then current ratio (0.75). On an overall assessment, the financial performance of KDCMPU in terms of current ratio is good.

Quick /Liquid/Acid Test Ratio: It shows the relationship between quick assets \& quick liabilities. It shows the business solvency or strength of liquidity. A Current Ratio of 2:1 was considered standard. A firm that had additional sufficient quick assets available to creditors was believed to be in sound financial condition. The Quick Ratio assumes that all assets are of equal liquidity. Here quick assets refer to current assets minus inventory and current liabilities here refer to current liabilities minus bills. That are calculated as follows: Quick ratio= Quick assets/ Current Liabilities

Table 2: Quick Ratio

\begin{tabular}{|l|l|l|l|l|l|l|}
\hline Year & $\begin{array}{l}\text { Quick } \\
\text { Assets }\end{array}$ & Trend \% & $\begin{array}{l}\text { Current } \\
\text { Liability }\end{array}$ & Trend \% & $\begin{array}{l}\text { Quick } \\
\text { Ratio }\end{array}$ & $\begin{array}{l}\text { Trend } \\
\%\end{array}$ \\
\hline 2006 & 16996669.7 & 100 & 10904221 & 100 & 1.56 & 100 \\
\hline
\end{tabular}




\begin{tabular}{|l|l|l|l|l|l|l|}
\hline 2007 & 17072924.9 & 100 & 10675663 & 98 & 1.60 & 103 \\
\hline 2008 & 20008109.38 & 118 & 15087836 & 138 & 1.33 & 85 \\
\hline 2009 & 19580964.01 & 115 & 13302519 & 122 & 1.47 & 94 \\
\hline 2010 & 36312748.18 & 214 & 19771186 & 181 & 1.84 & 118 \\
\hline 2011 & 43794810.09 & 258 & 24280474 & 223 & 1.80 & 116 \\
\hline 2012 & 57208473.5 & 337 & 36118351 & 331 & 1.58 & 102 \\
\hline 2013 & 152059263.9 & 895 & 32942965 & 302 & 4.62 & 296 \\
\hline 2014 & 189974194.4 & 1118 & 32065737 & 294 & 5.92 & 380 \\
\hline Average & $\mathbf{6 1 4 4 5 3 5 0 . 9}$ & $\mathbf{3 6 2}$ & $\mathbf{2 1 6 8 3 2 1 6 . 9 2}$ & $\mathbf{1 9 9}$ & $\mathbf{2 . 4 1}$ & $\mathbf{1 5 5}$ \\
\hline $\mathbf{r}$ & $\mathbf{0 . 8 5}$ & $\mathbf{0 . 9 3}$ & & $\mathbf{0 . 7 5}$ & \\
\hline
\end{tabular}

Source: Compiled from the records of KDCMPU

The ideal ratio of the firm should be $1: 1$, but the ratios of the company are above one from the year 2006 to the year 2014. It tells the business was in a position to pay the debts due within one year from assets that it expects to turn into cash within the year. The ratios of the company reach the target during the years 2006 (1.56), 2007 (1.60), 2008 (1.33), 2009 (1.47), 2010 (1.84), 2011 (1.80), 2012 (1.58), 2013 (4.62) and 2014 (5.92). The average liquid ratio rate is also positive to the tune of 2.41. The correlation analysis applied to find the relationship shows that though correlation is positive in all the three cases, the highest figure is recorded for current liabilities (0.93), the quick assets (0.85), and then quick ratio (0.75). On an overall assessment, the financial performance of KDCMPU in terms of quick ratio is good.

Debt-Equity Ratio: It measures the relation between debt and equity in the capital structure of the firm. In other words, this ratio shows the relationship between the borrowed capital and owner's capital, this ratio shows relative claim of the creditors and shareholders against the assets of the company. A high ratio here means less protection for creditors. A low ratio, on the other hand, indicates a wider safety cushion (i.e., creditors feel the owner's funds can help absorb possible losses of income and capital). This ratio is calculated as follows: Debt equity ratio=long term debt/shareholders' equity

Table 3: Debt Equity Ratio

\begin{tabular}{|l|l|l|l|l|l|l|}
\hline Year & Equity & Trend \% & Debt & Trend \% & DE Ratio & Trend \% \\
\hline 2006 & 1976301.39 & 100 & 9730994.47 & 100 & 4.92 & 100 \\
\hline 2007 & 1780719.39 & 90 & 14713263.72 & 151 & 8.26 & 168 \\
\hline 2008 & 1780719.39 & 90 & 14628488.47 & 150 & 8.21 & 167 \\
\hline 2009 & 1780719.39 & 90 & 14667238.47 & 151 & 8.24 & 167 \\
\hline 2010 & 1780719.39 & 90 & 14683988.47 & 151 & 8.25 & 167 \\
\hline 2011 & 8148387.26 & 412 & 14654738.47 & 151 & 1.80 & 37 \\
\hline 2012 & 8115200.34 & 411 & 14667784.47 & 151 & 1.81 & 37 \\
\hline 2013 & 4783170.92 & 242 & 14684478.47 & 151 & 3.07 & 62 \\
\hline 2014 & 20930373.11 & 1059 & 14708448.47 & 151 & 0.70 & 14 \\
\hline Average & $\mathbf{5 6 7 5 1 4 5 . 6 2}$ & $\mathbf{2 8 7}$ & $\mathbf{1 4 1 2 6 6 0 2 . 6 1}$ & $\mathbf{1 4 5}$ & $\mathbf{5 . 0 3}$ & $\mathbf{1 0 2}$ \\
\hline
\end{tabular}




\begin{tabular}{|l|l|l|l|l|l|l|}
\hline $\mathbf{r}$ & $\mathbf{0 . 7 5}$ & & $\mathbf{0 . 5 5}$ & & $\mathbf{- 0 . 7 3}$ & \\
\hline
\end{tabular}

Source: Compiled from the records of KDCMPU

Generally higher the ratio greater is the possibility of increasing the ROR to equity \& vice versa. A high debt equity ratio may be adopted to take advantage of cheaper debt capital. The ratio indicates the extent to which the firm depends upon outside for its existence. The ratio provides margin of safety to the creditors. It tells owners the extent to which they can gain benefits of maintaining control with a limit investment. General Standard of Debt Equity ratio is 2:1, but the company reaches the target throughout the period under study from 2006 to 2010, but is low during the years from 2011 and 2012 and is very low in the year 2014. On an average Shareholders' Equity has raised to 187 percent, Debt to 45 percent and Debt Equity Ratio to just 2 percent. High ratios unfavorable to the firm and high debt company are called leveraged or geared \& low debt equity ratio indicates grater claim of owners than creditors. Hence it is inferred from the analysis that the Aavin has given full protection to its owners by keeping low rate of debt equity ratio during the year 2014. The correlation is high for the Shareholders' Equity (0.75), debt (0.55) and is negative for Debt Equity Ratio (-0.73).

Proprietary Ratio: It establishes relationship between the propitiator or shareholders' funds \& total tangible assets. The proprietary ratio also known as net worth ratio or equity ratio is used to evaluate the soundness of the capital structure of a company. It may be expressed as: Proprietary ratio $=$ proprietary funds/total assets $* 100$. Higher the ratio lowers the risk and lower the ratio higher the risk. Debt -equity ratio and current ratio affects the proprietary ratio.

Table 4: Proprietary Ratio

\begin{tabular}{|l|l|l|l|l|l|l|}
\hline Year & $\begin{array}{l}\text { Proprietary } \\
\text { Funds }\end{array}$ & $\begin{array}{l}\text { Trend } \\
\text { \% }\end{array}$ & Total Assets & $\begin{array}{l}\text { Trend } \\
\text { \% }\end{array}$ & $\begin{array}{l}\text { Proprietary } \\
\text { ratio }\end{array}$ & $\begin{array}{l}\text { Trend } \\
\text { \% }\end{array}$ \\
\hline 2006 & 1976301.39 & 100 & 35381072.5 & 100 & 5.59 & 100 \\
\hline 2007 & 1780719.39 & 90 & 40306878.7 & 114 & 4.42 & 79 \\
\hline 2008 & 1780719.39 & 90 & 44691745 & 126 & 3.98 & 71 \\
\hline 2009 & 1780719.39 & 90 & 44338588.3 & 125 & 4.02 & 72 \\
\hline 2010 & 1780719.39 & 90 & 57804350.7 & 163 & 3.08 & 55 \\
\hline 2011 & 8148387.26 & 412 & 67173547.5 & 190 & 12.13 & 217 \\
\hline 2012 & 8115200.34 & 411 & 82075615.8 & 232 & 9.89 & 177 \\
\hline 2013 & 4783170.92 & 242 & 93222135.7 & 263 & 5.13 & 92 \\
\hline 2014 & 20930373.11 & 1059 & 98720778.94 & 279 & 21.20 & 380 \\
\hline Average & $\mathbf{5 6 7 5 1 4 5 . 6 2}$ & $\mathbf{2 8 7}$ & $\mathbf{6 2 6 3 4 9 6 8 . 1 2}$ & $\mathbf{1 7 7}$ & $\mathbf{7 . 7 2}$ & $\mathbf{1 3 8}$ \\
\hline r & $\mathbf{0 . 7 5}$ & & $\mathbf{0 . 9 7}$ & & $\mathbf{0 . 6 6}$ & \\
\hline
\end{tabular}

Source: Compiled from the records of KDCMPU

With regards to proprietary funds the growth rate is stagnant till 2010 and then wider to large extent while the total assets have a steady increase which causes the fluctuation in the proprietary ratio. The study shows that the KDCMPU is in a position to be independent based on more on equity than in debt. High ratio is evident during the year 2014 with 21.20 which is followed by 12.13 in the year 2011 and 9.89 in the year 2012. The ratio is comparatively low during the years 2008 (3.98), 2009 (4.02) and 2010 (3.08). The average growth rate over the years from 2006 to 
2014 indicates that it has growth rate of 187 percent for propriety funds, 77 percent for total assets and 38 percent for Proprietary ratio. The correlation is high for the total assets (0.97), propriety funds (0.75) and for Proprietary ratio (0.66).

Inventory / Stock Turnover Ratio (ITR/STR): The inventory turnover ratio is a common measure of the firm's operational efficiency in the management of its assets. It indicates the efficiency of firm in producing and selling its products. High Ratio is good from the view point of liquidity and vice versa. A low ratio would signify that inventory does not sell fast and stably in the warehouse for a longtime. It is calculated as follows: Inventory Turnover Ratio=Cost of Goods Sold/Average Inventory where cost of Goods Sold = Sales - Gross Profit while Average Inventory $=$ Opening Stock + Closing Stock $/ 2$

Table 5: Inventory Turnover Ratio of Aavin Industry

\begin{tabular}{|l|l|l|l|l|l|l|}
\hline Year & $\begin{array}{l}\text { Cost of Goods } \\
\text { Sold }\end{array}$ & $\begin{array}{l}\text { Trend } \\
\text { \% }\end{array}$ & $\begin{array}{l}\text { Average } \\
\text { Inventory }\end{array}$ & $\begin{array}{l}\text { Trend } \\
\%\end{array}$ & $\begin{array}{l}\text { Inventory } \\
\text { Turnover Ratio }\end{array}$ & $\begin{array}{l}\text { Trend } \\
\%\end{array}$ \\
\hline 2007 & 114198223.4 & 100 & 1867036.41 & 100 & 61.17 & 100 \\
\hline 2008 & 82871992.05 & 73 & 1914139.32 & 103 & 43.29 & 71 \\
\hline 2009 & 99574281.58 & 87 & 2573373.5 & 138 & 38.69 & 63 \\
\hline 2010 & 107421053.7 & 94 & 3230208.09 & 173 & 33.26 & 54 \\
\hline 2011 & 112948054.5 & 99 & 4632098.38 & 248 & 24.38 & 40 \\
\hline 2012 & 108560041.6 & 95 & 5925828.08 & 317 & 18.32 & 30 \\
\hline 2013 & 132630869 & 116 & 5616223.27 & 301 & 23.62 & 39 \\
\hline 2014 & 165005937.6 & 144 & 5181751.3 & 278 & 31.84 & 52 \\
\hline 2015 & 183123202.2 & 160 & 5434344.52 & 291 & 33.70 & 55 \\
\hline Average & 149969097 & 129 & 4612233.2 & 158 & 34.97 & 88 \\
\hline $\mathbf{r}$ & $\mathbf{0 . 8 4}$ & & $\mathbf{0 . 9 1}$ & & $\mathbf{- 0 . 6 8}$ & \\
\hline
\end{tabular}

Source: Compiled from the records of KDCMPU

As far as the Cost of Goods Sold is concerned, it is steadily increased from the year 2013 onwards after overcoming the fluctuations for the period from 2007 to 2012, for inventory the trend got fluctuated over the years under study which reflects in the inventory turnover ratio. The average growth rate is 29 percent for the cost of goods sold, 58 percent for the inventory and has lowered to the tune of 22 percent in case of inventory turnover ratio. The correlation is high for inventory (0.91) and cost of goods sold (0.84) and is negative for inventory turnover ratio (0.68). However the inventory turnover ratio of Aavin industry shows efficient management of inventory as the higher ratio says efficient business activities.

Debtors Turnover Ratio: Debtors' turnover ratio or accounts receivable turnover ratio indicates the velocity of debt collection of a firm. It shows number of times the receivables rotate in a year in times of sales and how quickly debtors are converted in to cash. Higher the ratio is better, since it indicate that debts are being collected more promptly. Debtor's turnover can be calculated by dividing total sales by balance of debtors. Debtors Turnover Ratio = Sales/Average Debtors 
Table 6: Debtors Turnover Ratio of Aavin Industry

\begin{tabular}{|l|l|l|l|l|l|l|}
\hline Year & Sales & Trend \% & $\begin{array}{l}\text { Average } \\
\text { Debtors }\end{array}$ & Trend \% & DT Ratio & Trend \% \\
\hline 2007 & 116465087.7 & 100 & 11320231 & 100 & 10.29 & 100 \\
\hline 2008 & 100011397.3 & 86 & 14035607 & 124 & 7.13 & 69 \\
\hline 2009 & 124094170.2 & 107 & 13138023 & 116 & 9.45 & 92 \\
\hline 2010 & 143714908.7 & 123 & 21557154 & 190 & 6.67 & 65 \\
\hline 2011 & 151419842.6 & 130 & 24703789 & 218 & 6.13 & 60 \\
\hline 2012 & 142345570.8 & 122 & 28471911 & 252 & 5.00 & 49 \\
\hline 2013 & 179191854.2 & 154 & 33590049 & 297 & 5.33 & 52 \\
\hline 2014 & 205725958.8 & 177 & 36485953 & 322 & 5.64 & 55 \\
\hline 2015 & 221790318.7 & 190 & 38082540 & 336 & 5.82 & 57 \\
\hline Average & $\mathbf{1 5 3 8 6 2 1 2 3 . 2}$ & $\mathbf{1 3 2}$ & $\mathbf{2 4 5 9 8 3 6 2}$ & $\mathbf{2 1 7}$ & $\mathbf{6 . 8 3}$ & $\mathbf{6 6}$ \\
\hline r & $\mathbf{0 . 9 5}$ & & $\mathbf{0 . 9 9}$ & & $\mathbf{- 0 . 7 9}$ & \\
\hline
\end{tabular}

Source: Compiled from the records of KDCMPU

The trend analysis in this connection reveals the fact that on an average the trend on sales have increased to 32 percent, debtors have increased to 117 percent whereas the Debtors Turnover Ratio has decreased to the tune of 44 percent. The correlation is positive and high in both the cases of sales (0.95) and Debtors (0.99) whereas the same for the Debtors Turnover Ratio is negative (-0.79). The Debtors Turnover Ratio is high during the initial years under study that is 10.29 in the year 2007, 9.45 in the year 2009 while the same is low in the year 2012. However, it is concluded from the study that it is good to reduce the debtors to boost up the profitability of the concern.

Creditor's Turnover Ratio: Accounts payable turnover is the ratio of net credit purchases of a business to its average accounts payable during the period. It measures short term liquidity of business since it shows how many times during a period, an amount equal to average accounts payable is paid to suppliers by a business. A higher value indicates that the business was able to repay its suppliers quickly. Thus higher value of accounts payable turnover is favorable. It indicates the speed with which the payment for credit purchases is made to creditors. This ratio is calculated as follows: Creditors Turnover Ratio $=$ Total Purchases $/$ Average Creditors

Table 7: Creditors Turnover Ratio of Aavin Industry

\begin{tabular}{|l|l|l|l|l|l|l|}
\hline Year & $\begin{array}{l}\text { Total } \\
\text { Purchases }\end{array}$ & $\begin{array}{l}\text { Trend } \\
\text { \% }\end{array}$ & $\begin{array}{l}\text { Average } \\
\text { Creditors }\end{array}$ & $\begin{array}{l}\text { Trend } \\
\text { \% }\end{array}$ & $\begin{array}{l}\text { Creditors } \\
\text { Turnover Ratio }\end{array}$ & $\begin{array}{l}\text { Trend } \\
\text { \% }\end{array}$ \\
\hline 2007 & 90719215.91 & 100 & 10227776.3 & 100 & 8.87 & 100 \\
\hline 2008 & 71638703.41 & 79 & 14283412.7 & 140 & 5.02 & 57 \\
\hline 2009 & 86553204.11 & 95 & 12667810.6 & 124 & 6.83 & 77 \\
\hline 2010 & 91775277.97 & 101 & 19144260.4 & 187 & 4.79 & 54 \\
\hline 2011 & 99230309.27 & 109 & 23702722.7 & 232 & 4.19 & 47 \\
\hline 2012 & 92013774.14 & 101 & 38948882.7 & 381 & 2.36 & 27 \\
\hline 2013 & 111234135.8 & 123 & 32373897.2 & 317 & 3.44 & 39 \\
\hline
\end{tabular}




\begin{tabular}{|l|l|l|l|l|l|l|}
2014 & 141491399.4 & 156 & 31477189.3 & 308 & 4.50 & 51 \\
\hline 2015 & 158903928 & 175 & 29125321.9 & 285 & 5.46 & 62 \\
\hline Average & $\mathbf{1 0 4 8 3 9 9 9 4 . 2}$ & $\mathbf{1 1 6}$ & $\mathbf{2 3 5 5 0 1 4 1 . 5}$ & $\mathbf{2 3 0}$ & $\mathbf{5 . 0 5}$ & $\mathbf{5 7}$ \\
\hline $\mathbf{r}$ & $\mathbf{0 . 8 6}$ & & $\mathbf{0 . 8 5}$ & & $\mathbf{- 0 . 5 9}$ & \\
\hline
\end{tabular}

Source: Compiled from the records of KDCMPU

The creditors' turnover ratio is fluctuating over the period from 2007 to 2015 which shows fluctuations in the credit position of the industry. The purchases increase steadily while the creditors' position finds ups and downs which are the major cause for the changes in the creditor turnover ratio. The trend analysis shows that on an average the total purchases attained a growth rate of 16 percent, Creditors 130 percent and the creditors' turnover ratio has got a negative growth rate of 43 percent. The correlation analysis shows a close relationship for the total purchases (0.86) and for Creditors (0.85) while the creditors' turnover ratio is negative to the tune of -0.59 over the years under study.

Gross Profit Ratio: Gross profit is the difference between sales and the manufacturing cost of goods sold. And gross profit is compared with the sales. Gross profit margin ratio reflects the efficiency with which management produces each unit of product. A high gross profit ratio is sign of goods management and implies that the firm is able to produce at relatively lower cost. A low gross profit margin reflects higher cost of goods sold due to Reduction in selling price, inefficient utilization of plant and machinery etc. It is calculated as follows: Gross Profit Ratio=Gross Profit/Net Sales*100

Table 8: Gross Profit Ratio of Aavin Industry

\begin{tabular}{|l|l|l|l|l|l|l|}
\hline Year & Gross Profit $(\mathbf{R s})$ & Trend \% & Sales & Trend \% & GP ratio & Trend \% \\
\hline 2007 & 2266864.31 & 100 & 116465088 & 100 & 1.95 & 100 \\
\hline 2008 & 17139405.25 & 756 & 100011397 & 86 & 17.14 & 880 \\
\hline 2009 & 24519888.62 & 1082 & 124094170 & 107 & 19.76 & 1015 \\
\hline 2010 & 36293855.02 & 1601 & 143714909 & 123 & 25.25 & 1297 \\
\hline 2011 & 38471788.12 & 1697 & 151419843 & 130 & 25.41 & 1305 \\
\hline 2012 & 33785529.16 & 1490 & 142345571 & 122 & 23.73 & 1219 \\
\hline 2013 & 46560985.22 & 2054 & 179191854 & 154 & 25.98 & 1335 \\
\hline 2014 & 40720021.22 & 1796 & 205725959 & 177 & 19.79 & 1017 \\
\hline 2015 & 38667116.51 & 1706 & 221790319 & 190 & 17.43 & 896 \\
\hline Average & $\mathbf{3 0 9 3 6 1 6 1 . 4 9}$ & $\mathbf{1 3 6 5}$ & $\mathbf{1 5 3 8 6 2 1 2 3}$ & $\mathbf{1 3 2}$ & $\mathbf{1 9 . 6 1}$ & $\mathbf{1 0 0 7}$ \\
\hline r & $\mathbf{0 . 8 5}$ & & $\mathbf{0 . 9 5}$ & & $\mathbf{0 . 4 9}$ & \\
\hline
\end{tabular}

Source: Compiled from the records of KDCMPU

The Aavin industry has got a steady flow in the earnings in the form of Gross Profit during the period under study which is witnessed through the trend analysis which reached its highest amount in the year 2013 with a growth rate of 1954 percent. The Gross Profit is comparatively lower during the initial periods under study that is 2007 and 2008. The average growth rate through trend analysis shows a growth rate of 1265 percent for the gross profit. The same is 
depicted in the sales also but at a slow growth wherein the sales was very low in the year 2008 and is high in the year 2015 and these changes of sales and gross profit have an impact on the Gross Profit ratio. The average growth rate through trend analysis shows a growth rate of 32 percent for sales. The Gross Profit ratio which is the result of both Gross Profit and sales has an average growth rate of 907 percent over the period under study. The correlation for both the gross profit as well as sales have an positive and good degree to the tune of 0.85 and 0.95 respectively whereas the correlation for the Gross Profit ratio has come down to 0.49.

Net Profit Ratio: Net Profit Margin is the profit represented in percentage of the revenue and also known by several names such as profit margin, net margin and net profit ratio. Profit margin may vary between different companies upon the competitive pricing strategy and the product mix of that company. This ratio indicates company's capacity to withstand adverse economic conditions. Depending on the concept of net profit employed, it is calculated as follows: Net Profit Ratio=Net Profit/Net Sales $* 100$

Table 9: Net Profit Ratio of Aavin Industry

\begin{tabular}{|l|l|l|l|l|l|l|}
\hline Year & Net Profit $($ Rs) & Trend \% & Sales & Trend \% & NP ratio & Trend \% \\
\hline 2007 & -5256557.12 & 0 & 116465088 & 100 & -4.51 & 0 \\
\hline 2008 & 182688.84 & 100 & 100011397 & 86 & 0.18 & 100 \\
\hline 2009 & 2708304.95 & 1482 & 124094170 & 107 & 2.18 & 1195 \\
\hline 2010 & 8951169.26 & 4900 & 143714909 & 123 & 6.23 & 3410 \\
\hline 2011 & 4968179.08 & 2719 & 151419843 & 130 & 3.28 & 1796 \\
\hline 2012 & 3061371.58 & 1676 & 142345571 & 122 & 2.15 & 1177 \\
\hline 2013 & 16280802.19 & 8912 & 179191854 & 154 & 9.09 & 4974 \\
\hline 2014 & 9296111.4 & 5088 & 205725959 & 177 & 4.52 & 2474 \\
\hline 2015 & 2888084.02 & 1581 & 221790319 & 190 & 1.30 & 713 \\
\hline Average & $\mathbf{4 7 8 6 6 8 3 . 8}$ & $\mathbf{2 9 4 0}$ & $\mathbf{1 5 3 8 6 2 1 2 3}$ & $\mathbf{1 3 2}$ & $\mathbf{2 . 7 1}$ & $\mathbf{1 7 6 0}$ \\
\hline r & $\mathbf{0 . 6 0}$ & $\mathbf{0 . 9 2}$ & & $\mathbf{0 . 5 5}$ & \\
\hline
\end{tabular}

Source: Compiled from the records of KDCMPU

The Aavin of Kanyakumari district was able to earn net profit from the year 2008 to 2015 except during the year 2007 in which the industry has suffered loss. This may be due to the over expenditure and low price for the milk. Due to this there is lot of fluctuations in the net profit ratio too. But the sale is steadily increasing. Taking 2008 as the base year, the trend has been calculated and it shows that the average growth rate for the net profit is 2840 percent, for the sales, it is 32 percent and 1670 percent for the net profit ratio. The correlation for the sales is high to the tune of 0.92 and moderate for both net profit $(0.60)$ and net profit ratio $(0.55)$.

Return on Assets (ROA): This ratio is an indicator of how profitable a company is relative to its total assets. ROA gives an idea as to how efficient management is at using its assets to generate earnings. This ratio is used to know the 'Productivity of the total assets'. The assets of the company are comprised of both debt and equity. The ROA figure gives investors an idea of how effectively the company is converting the money it has to invest into net income. The higher the 
ROA number, the better, because the company is earning more money on less investment. Return on Asset=Net Profit /Total Asset*100

Table 10: Return on Assets (ROA) of Aavin Industry

\begin{tabular}{|l|l|l|l|l|l|l|}
\hline Year & Net Profit (Rs) & Trend \% & $\begin{array}{l}\text { Total } \\
\text { Assets }\end{array}$ & Trend \% & ROA & Trend \% \\
\hline 2007 & -5256557.12 & 0 & 35381072.5 & 100 & -14.86 & 0 \\
\hline 2008 & 182688.84 & 100 & 40306878.7 & 114 & 0.45 & 100 \\
\hline 2009 & 2708304.95 & 1482 & 44691745 & 126 & 6.06 & 1337 \\
\hline 2010 & 8951169.26 & 4900 & 44338588.3 & 125 & 20.19 & 4454 \\
\hline 2011 & 4968179.08 & 2719 & 57804350.7 & 163 & 8.59 & 1896 \\
\hline 2012 & 3061371.58 & 1676 & 67173547.5 & 190 & 4.56 & 1006 \\
\hline 2013 & 16280802.19 & 8912 & 82075615.8 & 232 & 19.84 & 4377 \\
\hline 2014 & 9296111.4 & 5088 & 93222135.7 & 263 & 9.97 & 2200 \\
\hline 2015 & 2888084.02 & 1581 & 98720778.9 & 279 & 2.93 & 645 \\
\hline Average & $\mathbf{4 7 8 6 6 8 3 . 8}$ & $\mathbf{2 9 4 0}$ & 62634968.1 & 177 & 6.41 & 1779 \\
\hline r & $\mathbf{0 . 6 0}$ & & $\mathbf{0 . 9 7}$ & & $\mathbf{0 . 4 8}$ & \\
\hline
\end{tabular}

Source: Compiled from the records of KDCMPU

Due to the adverse effect of the net profit the company has a negative rate on the return on assets during the year 2007 and for the rest of the rest of the years under study, the company was able to have positive results in the form of return on assets. The average growth rate for the net profit is 2840 percent, 77 percent growth for the total assets and 1679 percent for the return on total assets. The return on assets is high during the years 2010 (20.19) and 2013 (19.84) and is low during the years $2008(0.45)$ and 2015 (2.93). Though the correlation is positive and high for the total assets (0.97), the same is moderate $(0.60)$ in case of net profit and comparatively low for the return on assets (0.48). There is no proper utilization of total assets in the company.

Return on Investment (ROI): It is also called as overall profitability ratio or Return on capital employed (ROCE) Ratio. This ratio is the broadest measure of the overall performance of business firm. To calculate ROI, the benefit (return) of an investment is divided by the cost of the investment; the result is expressed as a percentage or a ratio. The higher ratio, the more efficient use of the capital employed. It is calculated on the bases of the following: Return on Investment $=$ Net Profit/total capital employed $* 100$ where Capital Employed $=$ Total Assets - Current Liabilities

Table 11: Return on Investment (ROI) of Aavin Industry

\begin{tabular}{|l|l|l|l|l|l|l|}
\hline Year & Net Profit (Rs) & Trend \% & $\begin{array}{l}\text { Capital } \\
\text { Employed }\end{array}$ & Trend \% & ROI & Trend \% \\
\hline 2007 & -5256557.12 & 0 & 24476851.5 & 100 & -21.48 & 0 \\
\hline 2008 & 182688.84 & 100 & 29631215.7 & 121 & 0.62 & 100 \\
\hline 2009 & 2708304.95 & 1482 & 29603909 & 121 & 9.15 & 1484 \\
\hline
\end{tabular}




\begin{tabular}{|l|l|l|l|l|l|l|}
2010 & 8951169.26 & 4900 & 31036069.3 & 127 & 28.84 & 4678 \\
\hline 2011 & 4968179.08 & 2719 & 38033164.7 & 155 & 13.06 & 2119 \\
\hline 2012 & 3061371.58 & 1676 & 42893073.5 & 175 & 7.14 & 1158 \\
\hline 2013 & 16280802.19 & 8912 & 45957264.8 & 188 & 35.43 & 5746 \\
\hline 2014 & 9296111.4 & 5088 & 60279170.7 & 246 & 15.42 & 2501 \\
\hline 2015 & 2888084.02 & 1581 & 66655041.9 & 272 & 4.33 & 703 \\
\hline Average & $\mathbf{4 7 8 6 6 8 3 . 8}$ & $\mathbf{2 9 4 0}$ & $\mathbf{4 0 9 5 1 7 5 1 . 2}$ & $\mathbf{1 6 7}$ & $\mathbf{1 0 . 2 8}$ & $\mathbf{2 0 5 4}$ \\
\hline $\mathbf{r}$ & $\mathbf{0 . 6 0}$ & & $\mathbf{0 . 9 6}$ & & $\mathbf{0 . 5 0}$ & \\
\hline
\end{tabular}

Source: Compiled from the records of KDCMPU

The return on investment is negative during the year 2007 due to the loss in the Aavin industry though the capital employed during that period is healthy. The correlation is positive in all the three cases which is 0.96 for the capital employed, 0.60 for the net profit and 0.50 for the return on investment. On an average, the net profit has shown an increase in the growth rate of 2840 percent, capital employed has shown a growth of 67 percent and return on investment 1954 percent. However, the return on investment has shown a fluctuating trend over the period under study which is high in the years 2013 (35.43) and 2010 (28.84) while the same is low 2008 (0.62) and 2015 (4.33).

\section{CONCLUSION}

Dairy development activities are encouraged and promoted all over the district and not restricted to specific areas. Kanyakumari district is the least milk producing district in Tamil Nadu. The producers have to accept the changing scenario and formulate their marketing strategies to sell their products. With regards to the financial performance of Kanyakumari Aavin Industry, ratio analysis has been applied and it is revealed that the average current ratio over the years under study has crossed the standard with 2.64, liquid ratio is 2.41, Debt Equity Ratio is 2 percent, 38 percent for Proprietary ratio, lowered to the tune of 22 percent in case of inventory turnover ratio, Debtors Turnover Ratio has decreased to the tune of 44 percent, creditors' turnover ratio has got a negative growth rate of 43 percent, Gross Profit ratio which is the result of both Gross Profit and sales has an average growth rate of 907 percent over the period under study, 1670 percent for the net profit ratio, 1679 percent for the return on total assets and return on investment 1954 percent. The financial performance of Aavin industry in Kanyakumari District is good in all the aspects. As there is wider scope for the production as well as consumption of milk and milk products in the district, efforts can be made to reduce the cost and to maximize the profit to make the milk industry a vibrant and viable one in the district and state.

\section{REFERENCES}

[1] Annual Report of Kanyakumari District Co-operative Milk Producers Union

[2] Ashalatha, P.K., Rao, P., V.S.Ready, and R.S. Moorthy (2004): Impact of dairy cooperative on the milk production, consumption and marketed surplus pattern on the members. Indian J.Dairy Sci. 57(1) 60-64.

[3] Bandopadhay (2007). Emerging choices of Indian agriculture to agripreneurs. Paper presented at the winter school on advanced extension strategy for entrepreneurship 
development and management, ICAR, NewDelhi and Bidhan Chandra Krishi Viswavidyalaya, West Bengal, 4-24 December.

[4] Bardhan, D (2010), Factors influencing farmers' willingness to pay for animal health services and preference for private veterinary practitioners. Indian J. Anim. Sci., 80 (8): 790-797

[5] Thirunavukkarasu, D. and Sudeepkumar, N. K.,( 2005), Milk marketing options for dairy farmers in open economy and their choice in Tamil Nadu, India. Livestock Research for Rural Development, 17 (8).

[6] Saravanakumara V Jainb DK (2009), Evolving Milk Pricing Model for Agribusiness Centres: An Econometric Approach, Agricultural Economics Research Review 22: 155160.

[7] Shah P (2012), Exploring the Cost of Milk Production \& Potential Economies of Scale in a Dairy Cooperative. University of Pennsylvania Scholarly Commons Wharton Research Scholars Journal

[8] www.dairyindustry.co.in

[9] www.dairyindustry.org.on 